\title{
THE CHILD'S RIGHT TO MAINTAIN CONTACT WITH BOTH PARENTS IN THE AGE OF PANDEMIC
}

\author{
Ana Radina, PhD, Assistant Professor \\ Faculty of Law, University of Split \\ Domovinskog rata 8, 21000 Split, Croatia \\ ana.radina@pravst.hr
}

\begin{abstract}
The COVID-19 pandemic and the accompanying extraordinary measures engaged restrictions of fundamental human rights and liberties to an unprecedented scale. Inevitably, this had implications in the family context as well. Even though children are not considered to be an endangered category from a medical perspective, they are adversely affected by the pandemic in practically all aspects of life, in the short-term and in the long-term. One of the child's rights directly affected is the right to maintain direct contact with both parents on a regular basis. Digital means of communication can somewhat mitigate the lack of personal contact, however, not everyone has access to the necessary technologies and there might be various disagreements about exercising such indirect contact. The closure of judiciary and social services placed the burden of resolving contact related disputes almost entirely upon parents. This paper aims to examine the relevant legal framework and measures taken in relation to the child's right to maintain contact with both parents in the circumstances of the pandemic, with particular focus on the Croatian context and the response of the Croatian authorities to the challenges arising from this extraordinary situation, and to identify actions which could be taken in order to improve the child's unfavourable position.
\end{abstract}

Keywords: best interests of the child, child's rights, contact, COVID-19, pandemic, parents, restrictions

\section{INTRODUCTION}

There were several key implications for children arising from the pandemic ${ }^{1}$, and here we are focused on the implications in the family context, specifically the right to contact with both parents. Achieving and maintaining child-parent contact

1 Council of Europe, The COVID-19 pandemic and children: Challenges, responses and policy implications, 2021, [https://rm.coe.int/covid-19-factsheet-revised-eng/1680a188f2], Accessed 9 June 2021, p. 1. 
arrangements is often a challenging process within the 'regular' circumstances. Confinement and other restrictive measures have contributed to limiting the child's contact with the non-resident parent, increasing the risk of parental alienation, delaying the proceedings relating to contact, and the difficulties in enforcing court-orders on visitation rights ${ }^{2}$. Due to the closure of judiciary and social services, which could have been accessed to only in urgent situations that could not be remedied otherwise, the primary responsibility and the greatest burden for resolving issues concerning contacts during the pandemic was placed upon parents themselves, but therein lies a great potential for conflicts.

Certain recommendations and guidance were issued for parents and other carers regarding child contact arrangements during pandemic. Generally, it was recommended that during the lock-down the contacts be exercised indirectly, by using distance communication means if it was not possible otherwise due to the risk of infections, and after the quarantine ended, it was recommended that the contact arrangements envisaged by existing decisions are to be maintained, subject to respecting the best interests of the child as a primary concern and to abiding to all COVID-19 related measures. Digital means of communication can somewhat mitigate the lack of personal contact, however, not all children and parents have access to the necessary technologies; also, some parents might not have agreed to such a substitute for direct contact regardless of the health risks. It is also likely that some parents have used the pandemic related restrictions to obstruct or prevent the child having regular contact with the other parent.

Being mindful of the fact that maintaining contact is not only the right of the child, but also the right and the duty of the parents ${ }^{3}$, we will examine the relevant legal framework, international (United Nations, Council of Europe, European Union) and Croatian, dealing with contacts concerning children from the perspective of the child's right to maintain contacts with both parents. Child's right should be of greater importance with its parents being obligated to adapt to the circumstances that necessarily changed in the COVID-19 pandemic. After all, it is generally accepted that the child's rights are more than a moral category as they are recognized in international law ${ }^{4}$, and that the parents' duties exist as a correlation of the child's rights because the parents are the ones responsible to enable the

Ibid., p. 14.

3 Within the international, regional and national legal framework it is recognised that other family members and other persons close to the child have the right to contact with the child, however, due to limited space available, this paper does not deal with that aspect of the issue of contact concerning children.

4 Jakovac-Lozić, D., Susreti i druženja djeteta s odvojenim roditeljem u presudama Europskog suda za ljudska prava, Zbornik Pravnog fakulteta u Zagrebu, Vol. 55, No. 3-4, 2005, p. 872. 
child to exercise its rights ${ }^{5}$. Focusing on the issue of child-parent contact in the Croatian pandemic related context, we will examine how the domestic authorities responded to the pertaining challenges. We will use the analysis of the legal framework and domestic measures taken for the purposes of finding guidance as to what could be done to mitigate as much as possible the negative effects of restrictions brought about by the pandemic.

\section{INTERNATIONAL AND REGIONAL LEGAL FRAMEWORK}

\subsection{United Nations Convention on the Rights of the Child (1989)}

Whenever in search for answers regarding a child's right, the United Nations Convention on the Rights of the Child (1989) $)^{6}$ (CRC) is a common starting point. It is a kind of "world constitution" of the rights of the child that the international community accepts, ${ }^{7}$ and it is also the first instrument that guaranteed the child's right to maintain contact with both parents on the international level ${ }^{8}$. The CRC provides the basis for understanding the significance attached to the family and the indispensable role that parents are expected to play in the realisation of all the child's rights.

By prescribing the obligation of the States Parties to respect the right of the child to preserve its identity, including also family relations, (art. 8) the CRC treats preserving connections with its family as an element of the of the child's right to identity. ${ }^{9}$ Fundamental in this context is art. 9 which unambiguously lays the principle of not separating the child from its parents against their will, except when competent authorities decide so, thus making it obvious that the child's right to maintain contact with its parents is one of the most important rights in the family context; it reflects the goal of ensuring the child has the opportunity to be cared for by its parents and, in case of their separation, to maintain meaningful contact with a non-resident parent. ${ }^{10}$

Alinčić, M.; Hrabar, D.; Jakovac-Lozić, D.; Korać Graovac, A., Obiteljsko pravo, Narodne novine, Zagreb, 2007, p. 222.

6 Konvencija o pravima djeteta, Službeni list SFRJ - Međunarodni ugovori, no. 15/90, Narodne novine - Međunarodni ugovori, no. 12/93, 20/97, 4/98, 13/98. Available in English at: [https://www.ohchr. org/en/professionalinterest/pages/crc.aspx], Accessed 17 February 2021.

7 Lopatka, A., An Introduction to the United Nations Convention on the Rights of the Child, Transnational Law and Contemporary Problems, vol. 6, 1996, p. 252.

$8 \quad$ Rešetar, B., Pravna zašttita prava na susrete i druženje, Pravni fakultet u Osijeku, 2011, p. 118.

9 Vučković Šahović, N.; Petrušić, N., Prava deteta, Pravni fakultet Univerziteta u Nišu, 2016, p. 108.

10 Khazova, O.A.; Mezmur, B.D., Continued Reflections on Family Law Issues in the Jurisprudence of the CRC Committee: The Convention on the Rights of the Child @ 30, in: Brinig, M. (ed.), International Survey of Family Law, Intersentia, Cambridge-Antwerp-Chicago, 2020, p. 339. 
Such separation may have different causes, including the measures taken by the state against the parents or the children (e.g. deprivation of parental responsibilities, taking the child into public care), natural causes (e.g. natural disasters) or external causes (e.g. armed conflict, political unrest). ${ }^{11}$ The impossibility or at least a severely limited possibility of maintaining contact between the child and its parents during the COVID-19 related lock-down could not be fit strictly into one of these categories but rather it seems that it would represent a sort of fusion of different reasons as grounds for their separation.

In the context of potential separation of a child from its parents it is indispensable to carry out the assessment and determination of the child's best interests. ${ }^{12}$ Namely, in accordance with CRC art. 3/1, in all actions concerning children, whether undertaken by public or private bodies, the best interests of the child shall be a primary consideration. However, applying the standard of the best interest of the child is often complicated as it is, and the pandemic raised the level of difficulty very high. The state of emergency caused by COVID-19 pandemic put states in a tough position as they were faced with conflicting demands of having to meet the child's best interest's by enabling it to maintain contact with both parents, while at the same time fulfilling the child's best interest in protecting its health ${ }^{13}$ and development. Furthermore, the state has to respect the rights and duties of parents ${ }^{14}$ and it must protect the public interests, namely through protecting the health of its citizens which also touches upon the interests of the child as it concerns the protection the state had to provide for the members of the child's family.

According to CRC art. 3/2, the state is to take all appropriate measures in order to provide the child such protection and care as is necessary for his or her well-being. Considering this provision in the context of pandemic, all the measures that states imposed, as restrictive as they were, could now be considered as "appropriate" since they were aimed at protecting the child and its family, thus protecting the child's interests.

11 Vučković Šahović; Petrušić, op. cit., note 9, pp. 146-147.

12 Right to preservation of the family environment and maintaining relations is one of the elements that have to be taken into account when determining the best interest of the child. UN Committee on the Rights of the Child, General comment No. 14 (2013) on the right of the child to have his or her best interests taken as a primary consideration (art. 3, para. 1), CRC/C/GC/14, 29 May 2013, [https:// www2.ohchr.org/English/bodies/crc/docs/GC/CRC_C_GC_14_ENG.pdf].. pt. 58, Accessed 28 January 2021. More details: Ibid., pts. 58-70.

13 'Care' in CRC art. 3/2 must be interpreted broadly to take account of the health care rights. See more in: Freeman, M., A Commentary on the United Nations Convention on the Rights of the Child, Article 3: The Best Interests of the Child, Martinus Nijhoff Publishers, Leiden-Boston, 2007, p. 68.

14 In accordance with CRC art. 3/2. More details in: Ibid., pp. 69-71. 
Certain obligations of the states are focused directly on enabling the child to exercise its right to personal contact with its parents in case that parent resides in a different state, and the restrictions in that area may be justified only if they are prescribed by law, necessary to protect e.g. public health, and consistent with the other rights recognized in the CRC (art. 10). Maintaining contact with the nonresident parent if they are separated by state borders becomes especially difficult for the child ${ }^{15}$. Crossing the state borders during the global lock-down was practically impossible which also suggests depriving children in such situation of the right to maintain contact with their parents. However, considering the grounds for introducing them, it would be hard to argue successfully that those restrictions fall into category of 'unjustified'.

The child's right to maintain contact with both parents reflects the principle of art. 18 that both parents have common responsibilities for the upbringing and development of the child. ${ }^{16}$ Parents are the primary bearers of those responsibilities, while the state has a duty to extend appropriate assistance to parents if they lack abilities to perform their responsibilities. Realisation of the child's rights depends on its family and particularly parents being aware that it is upon them to provide the child with appropriate direction and guidance in the exercise of its rights, in a manner consistent with the evolving capacities of the child (CRC art. 5). What should be observed here is that by using the term "parental responsibilities", the CRC suggests a partnership between parents and children ${ }^{17}$ and the parents should be fully aware of the crucial significance for the child of them adequately fulfilling their role.

In art. 12 it is established that every child has the right to freely express its views in all matters affecting it, as well as the right for those views to be given due weight, according to the child's age and maturity. Also, the child has a right to be heard directly or indirectly through a representative in all proceedings affecting it. These provisions emphasize the importance of participation and respect for the personality of the child ${ }^{18}$, and impose a clear legal obligation on states parties to recognize this right and ensure its implementation ${ }^{19}$. At the same time, it is also important that parents encourage and facilitate their children in expressing themselves freely

\footnotetext{
15 Khazova; Mezmur, op. cit., note 10, p. 340.

16 Hodgkin, R.; Newell, P., Implementation Handbook for the Convention on the Rights of the Child, United Nations Children's Fund, Geneva, New York, 2007, p. 130.

17 Lopatka, op. cit., note 7, p. 255.

18 Ibid., p. 256.

19 UN Committee on the Rights of the Child, General Comment No 12 (2009): The right of the child to be heard, CRC/C/GC/12, 20 July 2009, [https://www2.ohchr.org/english/bodies/crc/docs/AdvanceVersions/CRC-C-GC-12.pdf], pt. 15, Accessed 28 January 2021.
} 
in accordance with art. 12 considering the family is the first point of social contact for the child ${ }^{20}$. When it comes to decision making process of the competent authorities, their determination of the child's best interest necessarily requires including the child itself. ${ }^{21}$

The CRC treats family as a unit primarily responsible for the child and the most important place for realisation of the child's rights, while at the same time it obliges the states to provide support to families lacking abilities to fulfil their functions adequately. Therefore, the international law does not abandon the child to the exclusive responsibility of the family, especially when the child finds itself in an unfavourable situation. ${ }^{22}$ However, confinement measures, quarantine, and lockdown engaged most intense restrictions of human rights and freedoms in general, and they inevitably prevented states in providing that support to families to a great extent. It seems safe to conclude that it all reflected negatively on the child's well-being.

\subsection{Council of Europe}

\subsubsection{Convention for the Protection of Human Rights and Fundamental Freedoms (1950)}

When talking about the Council of Europe Convention for the Protection of $\mathrm{Hu}-$ man Rights and Fundamental Freedoms (ECHR) ${ }^{23}$ in connection to the protection of human rights of the family members as well as the child's rights with regard to its family, we are referring to the right to respect for family life, as guaranteed to everyone by its art. 8, as well as to the case-law of the European Court of Human Rights $^{24}$ (ECtHR).

It is a widely accepted opinion that the ECtHR has given a significant contribution to strengthening of children's rights in Europe ${ }^{25}$ notwithstanding the fact the

20 Parkes, A., Children and International Human Rights Law: The Right of the Child to be Heard, Routledge, London, 2013, pp. 41-42.

21 Bubić, S., Standard najbolji interes djeteta i njegova primjena u kontekstu ostvarivanja roditeljskog staranja, Zbornik radova Dani porodičnog prava 'Najbolji interes djeteta u zakonodavstvu i praksi”, Pravni fakultet Univerziteta "Džemal Bijedić” u Mostaru, Mostar, 2014, p. 13.

22 Vučković Šahović; Petrušić, op. cit., note 9, p. 140.

23 Konvencija za zaštitu ljudskih prava i temeljnih sloboda te Protokoli br. 1, 4, 6, 7, 11, 12, 13, 14, 15, Narodne novine - Međunarodni ugovori, no. 18/97, 6/99, 14/02, 13/03, 9/05, 1/06, 2/10, 13/17. Available in English at: [https://rm.coe.int/1680a2353d], Accessed 26 March 2021.

24 European Court of Human Rights was established as an organ of implementation of the ECHR. See Section II of the ECHR, art. 19 and following. Ibid.

25 Faye Jacobsen, A., Children's Rights in the European Court of Human Rights - An Emerging Power Structure, The International Journal of Children's Rights, 24:3, p. 549. 
ECHR does not explicitly mention that category of rights. The Court's approach to the more specific question of contact is to emphasise the vital nature of contact between parents and children in order to maintain the family life relationship in accordance with art. $8 .{ }^{26}$

It is well established in the Court's case-law that the mutual enjoyment by parent and child of each other's company constitutes a fundamental element of family life even when the relationship between the parents has broken down ${ }^{27}$. Interference with the right to family life may be justified only if, as follows from art. $8 / 2 \mathrm{ECHR}$, it is in accordance with the law, pursues a legitimate aim and can be regarded as necessary in a democratic society. It is up to the State to identify the legitimate aim of interference in the rights guaranteed by the $\mathrm{ECHR}^{28}$. In cases concerning family life, the protection of the rights and freedoms of others and the protection of health or morals are most frequently used legitimate aims and it seems safe to say the interferences related to restrictive measures imposed during pandemic could be placed under the both of these categories.

When parents do not live together, the relevant ECtHR case-law has set forth various obligations in an effort to put a halt to events that could cause a breakdown in the parent-child relationship ${ }^{29}$. In cases where contact disputes concerning children arise between parents, parents have the right to have measures taken with a view to them being reunited with their children, and it is an obligation for the domestic authorities to take such measures. ${ }^{30}$ Lack of cooperation between separated parents is not uncommon, however it is not a circumstance which can by itself exempt the authorities from their obligations, but instead it imposes on them an obligation to make effort to reconcile ${ }^{31}$ those conflicting interests ${ }^{32}$. It is also worth mentioning that not only the behaviour of contact-seeking parent should be taken into account, but also the behaviour of the parent with whom the child resides when there are allegations of manipulation of the child ${ }^{33}$. In sum, the states' posi-

26 Kilkelly, U., Children's Rights - A European Perspective, Judicial Studies Institute Journal, 2004, 4:2, 2004, p. 74.

27 E.g. Kacper Nowakowski v. Poland, no. 32407/13, 10 January 2017, $₫ 70$; Suur v. Estonia, no. 41736/18, 20 October 2020, \$71.

28 Harris, D.J.; O’Boyle, M.; Bates, E.P.; Buckley, M., Harris, O’Boyle \& Warbrick: Law of the European Convention on Human Rights, Oxford University Press, 2014, p. 509.

29 Roagna, I., Protecting the right to respect for private and family life under the European Convention on Human Rights, Council of Europe, Strasbourg, 2012, p. 70.

30 E.g. Ribić v. Croatia, no. 27148/12, 2 April 2015, \$89.

31 See Bubić, S., op. cit. note 21, p. 27.

32 See: Z. v. Poland, no. 34694/06, 20 April 2010, $\$ 75$.

33 More details in: Vertommen, E., Balancing the Rights of Parent and Child in Case on Non-Compliance with Contact Arrangements: A Case Law Analysis, in: Boele-Woelki, K.; Martiny, D. (eds.), Plurality and 
tive obligation is not one of a result, but one of means employed, and the key consideration is whether authorities have taken all necessary steps to facilitate contact as can reasonably be demanded given the circumstances of a specific case. ${ }^{34}$

Effective respect for family life requires that future relations between parent and child be determined in the light of all the relevant considerations, and not by the mere passage of time $e^{35}$, therefore, there is a duty to exercise exceptional diligence ${ }^{36}$. Furthermore, when assessing the compliance with the states' obligations under art. 8, the ECtHR requires that the fair balance is struck between the competing interests of the individual and the community, including other concerned third parties, and the state's margin of appreciation; it is necessary to take due account of the situation of all members of the family, as this provision guarantees protection to the whole family. ${ }^{37}$

As to the procedural requirements implicit in art. 8, what has to be determined is whether the parents have been involved in the decision-making process, seen as a whole, to a degree sufficient to provide them with the requisite protection of their interests ${ }^{38}$. The states' margin of appreciation in the field of child protection has historically been rather wide because of the complex and sensitive nature of these situations, which national authorities are usually in a better position to solve. ${ }^{39}$ However, stricter scrutiny is applied in respect of restrictions on contact rights, because such measures entail the danger of family relations between parents and child being effectively curtailed. ${ }^{40}$ The domestic courts are expected to conduct an in-depth examination of the entire family situation and of a whole series of factors (factual, emotional, psychological, material, medical), with the aim of finding the best solution for the child. ${ }^{41}$

Even though the ECHR does not mention the best interest of the child, in cases involving children the best interest test is now the accepted criteria for determining the compliance of the state interference with family life within the meaning of art. $8 \mathrm{ECHR}^{42}$. In cases involving the contact restrictions, the ECtHR emphasises

Diversity of Family Relations in Europe, Intersentia, Cambridge, 2019, pp. 194-196.

34 E.g. A.V. v. Slovenia, no. 878/13, 9 April 2019, \$ 74.

35 See: V.D. and Others v. Russia, no. 72931/10, 9 April 2019, \$ 116.

36 E.g. Ignaccolo-Zenide v. Romania, no. 31679/96, 25 January 2000, \$ 102.

37 See: Jeunesse v. the Netherlands [GC], no. 12738/10, 3 October 2014, \$\$106, 117.

38 See: A.K. and L. v. Croatia, no. 37956/11, 8 January 2013, $\$ 63$.

39 Roagna, op. cit., note 29, p. 49.

40 E.g. Pavel Shishkov, no. 78754/13, 2 March 2021, \$ 78; V. v. Slovenia, no. 26972/07, 1 December $2011, \$ 82$.

41 E.g. Petrov and X v. Russia, no. 23608/16, 23 October 2018, \$\$ 98-102.

42 Kilkelly, op. cit., note 26, p. 72. 
that the child's interests must come before all other considerations $s^{43}$ and that interests may, depending on their nature and seriousness, override those of the parents $^{44}$. The child's interests dictate that its ties with the family must be maintained, except in cases where the family has proved particularly unfit, but it is also in the child's interests to develop in a sound environment; therefore a parent cannot be entitled under art. 8 to have such measures taken which would harm the child's health and development. ${ }^{45}$ When it comes to realising the child's right to active participation in making decisions that affect its life, as guaranteed by the art. 12 $\mathrm{CRC}$, the Court finds it important that the due weight is given to the child's views and feelings ${ }^{46}$; however, those views in itself are not necessarily sufficient to override the parents' interests, especially in having regular contact with their child, without any other factors being considered..$^{47}$

It would seem that the general development of the Court's case-law does go in favour of the child's rights perspective, but the child's best interest is less influential in cases where its rights have to be balanced against parents' interests ${ }^{48}$ protected by the art. $8 \mathrm{ECHR}$. At the same time, this approach could also be seen as protecting their mutual long-term interest in protecting their right to contact, thus also protecting their right to family life ${ }^{49}$. In the context of COVID-19 confinement measures, what unfortunately follows from what is stated above is that most of the state's obligations imposed by the ECHR and the Court's case-law in the area of child's and parent's right to enjoy mutual company could probably not have been fulfilled.

\subsubsection{European Convention on the Exercise of Children's Rights (1996)}

European Convention on the Exercise of Children's Rights ${ }^{50}$ represented another step forward in the inauguration of children's rights by affirming the possibilities of the child to fulfil its interests in its own special way. Namely, this Convention

\footnotetext{
43 See: Strand Lobben and Others v. Norway, no. 37283/13, 10 September 2019, \$ 204.

44 E.g. Johansen v. Norway, no. 17383/90, 7 August 1990, \$ 78.

45 E.g. Kocherov and Sergeyeva v. Russia, no. 16899/13, 29 March 2016, \$ 95; Sommerfeld v. Germany [GC], no. 31871/96, 8 July 2003, \$ 64 .

46 More details on the application of art. 12 CRC in the case-law of ECtHR in: Parkes, op. cit., note 20, pp. 111-113; Vertommen, op. cit., note 33, pp. 183-184.

47 E.g. N.Ts. v. Georgia, no. 71776/12, 2 February 2016, \$ 72; C. v. Finland, no. 18249/02, 9 May 2006, \$\$ 57-58.

48 Faye Jacobsen, op. cit., note 25, pp. 566, 570.

49 Rešetar, op. cit., note 8, p. 137.

50 Europska konvencija o ostvarivanju dječjih prava, Narodne novine-Međunarodni ugovori, no. 1/10, 3/10. Available in English at: [https://rm.coe.int/168007cdaf], Accessed 12 April 2021.
} 
contains rules aiming at making it possible for the child to express its views in family proceedings. ${ }^{51}$ While it is not specified in which family proceedings the child's rights should be exercised, art. $1 / 3$ includes particularly those involving the issue of access to children. These proceedings have been chosen due to their importance for the child. ${ }^{52}$ Throughout the text of the Convention two important family law notions are restated - the idea that in proceedings concerning the child its best interests should be the primary consideration, and the right of the child to be informed and express its views in such proceedings. ${ }^{53}$

This Convention recognises the child's rights to receive all relevant information, to be consulted and express its views, and to be explained and informed of the possible consequences of compliance with these views and the possible consequences of any decision (art. 3). This is a guarantee of the child's right to actively participate in the proceedings, further followed by the right to apply for a special representative in art. $4^{54}$, in cases that the relevant domestic laws see as conflict of interests between the child and its parents. Also, in case of such conflict of interest, the court has the power to appoint a special representative for the child (art. 9). Even if parents are not the child's representatives within the meaning of this Convention, they should help their children in exercising their right to actively participate in the proceedings. In any case, the assistance provided to the child in view of exercising these rights must correspond to the child's level of maturity and understanding. ${ }^{55}$

The courts are required to ensure that, before taking any decision, they have sufficient information at their disposal, which means sufficient information to take a decision in the best interests of the child. The court must also perform its part in the exercise of the rights guaranteed in art. 3 by ensuring that children have been provided with all relevant information, consulting the child in person when it's appropriate, allowing the child to express its views and giving those views due weight (art. 6). ${ }^{56}$

51 Jakovac-Lozić, D., Međunarodne otmice djece od strane roditelja, Zbornik radova Pravnog fakulteta u Splitu, Vol. 34, No. 45-46, 1997, p. 87.

52 Council of Europe, Explanatory Report to the European Convention on the Exercise of Children's Rights, 1996, [https://rm.coe.int/CoERMPublicCommonSearchServices/DisplayDCTMContent?documentId=09000016800cb5ee], p. 3, Accessed 11 April 2021.

53 Nikolina, N., Divided Parents, Shared Children: Legal Aspects of (Residential) Co-Parenting in England, the Netherlands and Belgium, Intersentia, Cambridge-Antwerp-Portland, 2015, pp. 23-24.

54 Rešetar, op. cit., note 8, p. 139.

55 More details in: Council of Europe, op. cit., note 52, pp. 4-7.

$56 \quad$ Ibid., p. 7. 
In principle, these provisions should equip the child with tools that should enable it to effectively exercise its right to active participation in the proceedings regarding the issue of contacts. However, when considered in connection to all the restrictions that pandemic brought, it is hard to imagine that these rights could have been exercised anywhere close to a satisfactory level.

\subsubsection{Convention on Contact concerning Children (2003)}

Principles relevant for the child's right to contact with parents, particularly in the area of transfrontier contact, stem especially from the Convention on Contact concerning Children ${ }^{57}$ which is devoted entirely to improving the issues relating to exercising contact rights. This document provides further valuable elaboration of certain elements of this child's right and as such it can be considered to be complementary to the CRC.

This Convention emphasizes that the child and its parents have the right to maintain regular contact with each other. ${ }^{58}$ By using the term "contact", it reflects the contemporary tendencies that perceive the child not as an object to be accessed to, but as an active subject upon whose views, opinions and wishes sometimes depends the contact itself. 59

Three different forms of the right to contact concerning children are identified in art. 2: a) direct contact which includes the child staying for a limited period of time with or meeting with the parent; b) indirect contact which means any form of communication between the child and the parent, e.g. by telephone, letters, email, etc.; c) the provision of information to the parent about the child or to the child about the parent. The two latter levels of contact can be used in addition or instead of direct contact in specific circumstances when direct contact is not possible or it is contrary to the best interests of the child. ${ }^{60}$

Reiterating the significance attached to this right both for the child and the parents, art. 4 allows for restriction or exclusion of that right only where it is beyond

57 Konvencija o kontaktima s djecom, Narodne novine - Međunarodni ugovori, no. 7/08, 1/09. Available in English at: [https://rm.coe.int/168008370f], Accessed 25 January 2021.

58 Nikolina, op. cit., note 53, p. 24.

59 More in: Jakovac-Lozić, D., Europska konvencija o kontaktima u vezi s djecom (2003.) i prilagodba obiteljskog zakonodavstva Federacije Bosne i Hercegovine zahtjevima Konvencije de lege ferenda, Zbornik radova Aktualnosti građanskog i trgovačkog zakonodavstva i pravne prakse, no. 2, Mostar, 2004, pp. $155,157$.

60 Council of Europe, Explanatory Report to the Convention on Contact concerning Children, Strasbourg, 2003, [https://rm.coe.int/CoERMPublicCommonSearchServices/DisplayDCTMContent?documentId=09000016800d380d], p. 5, Accessed 25 January 2021. 
any doubt that the best interests of the child concerned require so. This means that no other less restrictive solution was available, but in any case ${ }^{\text {the }}$ court will have to duly justify the necessity of such decision61. This also makes it obvious that practical obstacles such as the fact the child and the parent reside in different states will not be sufficient grounds for restricting/denying contact ${ }^{62}$, as opposed to the case where contact represents physical or psychological jeopardy for the child from the part of its parent. $^{63}$

The child's procedural rights in the proceedings for deciding on the issue of contacts (art. 6) originate and are completely harmonised with the demands contained in the aforementioned European Convention on the Exercise of Children's Rights. ${ }^{64}$ Furthermore, the courts must ensure both parents are informed of the importance of regular contact and to encourage them in reaching amicable agreements ${ }^{65}$ to that end (art. 7), for instances through family mediation and other processes for resolving family disputes. Thus it could be said that this Convention sends out a positive message about the desirability of more intensive cooperation between the parents by promoting contact between both parents and the child despite practical obstacles ${ }^{66}$, as well as by obliging the competent authorities to motivate parents towards out-of-court ways of resolving their issues.

\subsection{European Union}

The European Union (EU) also has high regard for the child's right to maintain contact with both parents. Even though the EU does not have powers to directly influence national substantive family laws and/or children's rights in its Member States, the child's rights in general have been gaining more importance on the EU level.

The promotion of the rights of the child was set for the first time as one of the objectives of the EU in art. 3 of the Treaty of Lisbon ${ }^{67}$. Among the rights, freedoms and principles contained in the Charter of Fundamental Rights of the European

$61 \quad$ Ibid., pp. 8-9.

62 Nikolina, op. cit., note 53, pp. 24-25.

63 Council of Europe, op. cit., note 60, p. 9.

64 Lulić, M.; Rešetar, B., Međunarodne obveze Republike Hrvatske vezane uz provedbu Konvencije o kontaktima s djecom (2003), in: Rešetar, B. (ed.), Pravna zaštita prava na (zajedničku) roditeljsku skrb, Pravni fakultet u Osijeku, Osijek, 2012, p. 110.

65 The European Convention on the Exercise of Children's Rights also encourages mediation or similar processes for resolving disputes affecting children (see art. 13), op. cit., note 50.

66 Nikolina, op. cit., note 53, p. 25.

${ }_{67}$ Treaty of Lisbon amending the Treaty on European Union and the Treaty establishing the European Community, OJ C 306, 17.12.2007. 
Union $^{68}$ (Charter), protection of the family and the child's rights also found their place. The right of every individual to respect for his private and family life is guaranteed in art. 7 of the Charter, and its meaning and scope is to be interpreted in line with the corresponding right enshrined in the ECHR (art. 52/3 of the Charter). ${ }^{69}$

Without prejudice to children enjoying other human rights and freedoms set forth in the Charter, art. 24 highlights few of the child's rights which might be considered as especially important. ${ }^{70}$ It envisages the child's right to protection and care necessary for its well-being and requires that its best interests be a primary consideration in all actions concerning the child. Furthermore, it recognises the child's right to express its views freely on matters concerning it, as well as the right to have those views given due weight in accordance with the child's age and maturity. While these rights are certainly significant for resolving issues concerning the realisation of the child's right to contact with both parents, it is of particular importance that art. 24/3 explicitly prescribes the child's "right to maintain on a regular basis a personal relationship and direct contact with both his or her parents, unless that is contrary to his or her interests".

Therefore, among many child's rights, the creators of the Charter chose to accentuate the child's right to contact with both parents. The reason for this might be the fact the EU is based on the freedom of movement of people. The parent's changing of his habitual residence and/or domicile within the EU requires finding the way to enable the child to maintain personal contact with both parents ${ }^{71}$ in the new circumstances that include a cross-border element.

Respect for the child's right to maintain direct contact with both parents is apparent also in the provisions of the Council Regulation (EC) No 2201/2003 of 27 November $2003^{72}$, the so-called Brussels II bis regulation, which deals with jurisdiction, recognition and enforcement of judgments in matrimonial matters and matters of parental responsibility. Namely, this Regulation declares that it seeks to ensure respect for the fundamental rights of the child as set out in art. 24 of the Charter (recital 33, preamble of the Brussels II bis). Brussels II bis applies

\footnotetext{
68 Charter of Fundamental Rights of the European Union, OJ C 326, 26.10.2012.

69 See also the Consolidated version of the Treaty on European Union, OJ C 326, 26.10.2012, art. 6.

70 Korać Graovac, A., Povelja o temeljnim pravima Europske unije i obiteljsko pravo, in: Bodiroga-Vukobrat, N. et al. (eds.), Europsko obiteljsko pravo, Narodne novine, Zagreb, 2013, p. 45.

$71 \quad$ Ibid., p. 47.

72 Council Regulation (EC) No 2201/2003 of 27 November 2003 concerning jurisdiction and the recognition and enforcement of judgments in matrimonial matters and the matters of parental responsibility, repealing Regulation (EC) No 1347/2000, OJ L 338, 23.12.2003.
} 
in civil matters relating to parental responsibility, which include rights of access (art. 1/1(b), 1/2(a)). The right of access is defined as including "in particular the right to take a child to a place other than his or her habitual residence for a limited period of time" (art. 2/10). It is important to notice that the Brussels II bis regulation provides for a 'fast track' regime for recognition and enforcement of judgments on the rights of access ${ }^{73}$. Namely, if the right to contact is granted in an enforceable judgment in a Member State, it shall be recognised and enforceable in another Member State without the need for a declaration of enforceability and without the possibility of opposing its recognition, provided that the conditions laid down by this Regulation are fulfilled (art. 41); one of those conditions is that the child was given an opportunity to be heard (art. 41/2(c)) which also demonstrates the importance attached to the child's rights.

The role of the Court of Justice of the European Union (CJEU) is to make sure the EU law is interpreted and applied in the same way in all Member States ${ }^{74}$. Even though the search through the CJEU's case- law $^{75}$ so far does not reveal cases which would include both the issue of contact between the child and its parents and the COVID-19 related restrictions on freedom of movement, the available jurisprudence, albeit mainly concerning the issue of return of the child, offers valuable insight into the CJEU's approach in this area.

In the CJEU's case-law, the protection of the child and of the child's fundamental rights is considered to be a legitimate interest which, in principle, justifies a restriction of a fundamental freedom guaranteed by the Treaty on the Functioning of the European Union ${ }^{76}$ (TFEU). The conceptions regarding the level of protection and the related rules differ between Member States, but the CJEU does not consider it necessary that measures aimed at protecting the rights of the child be unified in all the Member States. ${ }^{77}$

73 McEleavy, P., Brussels II bis: Matrimonial Matters, Parental Responsibility, Child Abduction and Mutual Recognition, The International and Comparative Law Quarterly, Vol. 53, No. 2, 2004, p. 511. The author explains that the 'standard track' regime is reserved for matrimonial matters and the majority of matters of parental responsibility. The 'fast track' procedure is envisaged for the judgments on the rights of access and on the return of the child and is covered by the Chapter III, Section IV of the Brussels II bis regulation.

74 See Consolidated version of the Treaty on the Functioning of the European Union, OJC 326, 26.10.2012, art. 267.

75 See the official website of the CJEU: [https://curia.europa.eu/juris/recherche.jsf?language=en], Accessed 14 June 2021.

76 Consolidated version of the Treaty on the Functioning of the European Union, op. cit., note 74, art. 21.

77 C-454/19, 19 November 2020, $\$ \$ 40-42$. 
In cases where the issue of jurisdiction arises, the CJEU emphasises that the objective of Brussels II bis is meeting the best interests of the child, which is why it favours the criteria of proximity and entrusts the jurisdiction primarily to the courts of the Member State of the child's habitual residence ${ }^{78}$. Family environment is of particular importance when determining the infant's habitual residence, and that environment includes not only the parent with whom the child lives on a daily basis, but the other parent as well if the child maintains regular contact with that parent. $^{79}$

When application is made for change of the previously made decision on contacts, the CJEU established that if the courts of the Member State made a decision that became final concerning parental responsibility with regard to a minor child, they no longer have jurisdiction to alter that decision if the habitual residence of the child is in another Member State ${ }^{80}$. In case that an application relating to parental responsibility is made at the time when the child has already acquired its habitual residence in a third State, one cannot rely on indefinite retention of jurisdiction of the courts of the Member State of origin, as that would not be compatible with respecting the best interests of the child as one of the fundamental objectives pursued by the Brussels II bis regulation. ${ }^{81}$ In the context of the proceedings for the return of the child, Member States are not precluded from allocating to a specialised court the jurisdiction to examine questions of custody with respect to a child, under the condition that such an allocation of jurisdiction is compatible with the child's fundamental rights set out in art. 24 of the Charter, and that the procedures are conducted expeditiously. ${ }^{82}$

The importance attached to the child's right to maintain contact with both parents is also apparent from the fact the CJEU requires that art. 7 of the Charter, protecting the right to family life, be interpreted in a way that takes into consideration the child's best interests, and taking into account the fundamental right of a child to maintain regular contact with both parents ${ }^{83}$. Moreover, even though art. 24 of the Charter mentions only the parents as holders of the right to contact with the child, the CJEU confirmed that the grandparents' application to be granted rights of access to their grandchildren is also covered by the Brussels II bis regulation,

\footnotetext{
78 E.g. C393/18 PPU, 17 October 2018, \$\$ 48-49.

79 C512/17, 28 June 2018, especially $\$ \$ 48,65$.

80 C499/15, 15 February 2017, $\$ \$ 61-70$; father applied to the courts of his Member State seeking to change the child's place of residence, the amount of maintenance and the contact arrangements.

81 C-603/20 PPU, 24 March 2021, $\$ \$ 58,60,64$; father applied to the referring court seeking an order for the return of the child and a ruling on rights of access.

82 C-498/14 PPU, 9 January 2015, $\$ \$ 51-54$.

83 See e.g. C540/03, 27 June 2006, $\$ \$ 58$; C400/10 PPU, 5 October 2010, $\$ 60$.
} 
thus the concept of "rights of access" must be interpreted accordingly ${ }^{84}$. This view of the CJEU is in line with the commitment of the EU to respect the fundamental rights guaranteed by the ECHR as general principles of the Union's law (art. 6 TFEU).

Even though it is obvious that the EU, within the field of its powers, makes effort to provide protection to the child's right to maintain regular and direct contact with both parents, the objective barriers, resulting from the measures imposed in an effort to contain the COVID-19 pandemic, prevented to a large extent the realisation of this right in practice, especially in cases of the cross-border contact.

\section{CROATIAN FAMILY LAW APPROACH TO THE CHILD'S RIGHT TO CONTACT WITH BOTH PARENTS}

In Croatian family law parental responsibilities represent a sum of duties, rights and privileges whose purpose is to promote and safeguard the child's rights and welfare in accordance with the child's developing capacities, including the child's health and development, and enjoying and maintaining personal relations. ${ }^{85}$ The Family Act $(2015)^{86}$ (FA) requires of parents to discuss and agree upon the individual aspects of parental care with the child, according to the child's age and maturity. Parents are not allowed to waive their right to parental responsibility (art. 91), nor to transfer this right to another person, which is why this right is placed among personal and subjective rights and constitutes an element of the individual's personal status ${ }^{87}$.

Widely accepted views about contact with both parents as being in the best interest of the child and the overall goals in that regard incited significant shift in the regulation of this dimension of relations within the families ${ }^{88}$, so it is not surprising that the gradual development in this area led to this right of the child currently being placed among the fundamental principles of the FA (art. 5/2), together with

84 C-335/17, 31 May 2018, $\$ \$ 33,37$; the referring court requested a preliminary ruling on the question whether the concept of "rights of access" encompasses also the child's access to relatives other than the parents, in this case the grandparents.

85 Korać Graovac, A., Zajednička roditeljska skrb u praksi Europskog suda za ljudska prava - slučaj Zaunegger v. Germany, in: Rešetar, B. (ed.), Pravna zaštita prava na (zajedničku) roditeljsku skrb, Pravni fakultet u Osijeku, Osijek, 2012, p. 72.

86 Obiteljski zakon, Narodne novine, no. 103/15, 98/19, 47/20.

87 Alinčić; Hrabar; Jakovac-Lozić; Korać Graovac, op. cit., note 5, p. 219. While the parents may not transfer the right to parental responsibility itself, they are allowed to transfer parts of parental responsibilities to third persons, e.g. by temporarily transfering daily care to third persons or to an institution. See arts. 102 and 103/1 of the FA.

88 Jakovac-Lozić, op. cit., note 4, p. 880. 
the primary right, duty and responsibility of parents to live with and care for their child (art. 6). It is the duty of courts and public bodies adjudicating in cases affecting children's rights to protect the rights of the child and its well-being before all (art. 5/1). Encouraging amicable resolution of family matters is prescribed as a task of everyone included in providing the family with professional assistance or decide on family relations (art. 9).

Right to live with its family which includes both parents is indispensable for the child's emotional stability, however this is a relative right and it will not always be possible to exercise it ${ }^{89}$, for example, in the case the parents' divorce. In such cases the child's right to contact with both parents serves as a kind of substitute. ${ }^{90}$ The child's right to contact with the non-resident parent is prescribed as one of the child's personal rights (art. 84/4), while at the same time the right and duty to protect the child's personal right to contact is declared as one of the basic elements of parental care (art. 92/1). Forbidding or restricting the parent's right to contact with the child is possible only by a court's decision if such a measure is necessary for the protection of child's well-being (art. 123). ${ }^{91}$

Different forms of contact between the child and the parent derive entirely from the aforementioned Convention on Contact concerning Children; thus the FA provides for direct contacts (the child staying with the parent or meeting with the parent for a limited period of time); indirect contacts (using available means of communication, e.g. telephone, SMS, etc.; providing of information to the parent about the child and vice versa (art. 121).

Furthermore, aiming at the realisation of the child's right to contact to the widest possible extent, the legislator imposed certain specific duties upon both parents. The non-resident parent has the right and duty to maintain personal contacts notwithstanding this parent's right to exercise the parental care (arts. 95/1, 112); the parent with whom the child resides has a correlative duty to enable and encourage maintaining contacts of the child with the other parent, and to refrain from acting in a way that could hinder those contacts (arts. 95/2, 119). Duties of the resident parent could be seen as part of the legislator's attempts to demonstrate the parents just how important for the child's life is maintaining contact with both of them. Parents should be made aware that the legislator also provided for sanctions in case they breach those duties. Namely, FA prescribes in art. 126 that the parent has to compensate the damages caused to the other parent by not complying with

Hrabar, D., Dijete - pravni subjekt u obitelji, Zagreb, 1994, pp. 94-96.

Alinčić; Hrabar; Jakovac-Lozić; Korać Graovac, op. cit., note 5, p. 246.

Conditions for making such a decision are prescribed in accordance with the Convention on Contact concerning Children, see supra, section. 2.2.3. and art. 123/2 of the FA. 
the court's decision on the contact of the latter with the child without justifying reasons for his actions.

In the spirit of encouraging cooperation for the sake of the child's best interest, the legislator provided the parents with possibility of reaching an agreement on exercising contacts with the child (art. 122). Also, parenting plan $^{92}$ is a written agreement of parents on the manner of the exercise of the joint parental responsibility, including the child's contact with both parents, in the circumstances of them permanently not living in a family union. Moreover, parents are required to inform their child of the content of the parenting plan, provide it with the opportunity to express its opinion, and give that opinion due weight (art. 106).

Parents may also initiate the non-contentious proceedings related to maintaining of contact with the child. However, prior to initiating such proceedings they are obliged to attend mandatory counselling ${ }^{93}$ (arts. 322/1, 329/1(8), art. 478/4) at the social welfare centre. Specific aims of this procedure are making participants aware of their duty to take account of the child's well-being when deciding on their family disputes, of the negative effects of such disputes on the child, of the advantages of amicable resolutions of family matters, of the duty of parents to take into account the child's views, and informing the participants about the possibility of resolving their disputes in the context of family mediation (art. 330).

Family mediation is another out-of-court option that the FA provides for parents who need professional assistance in resolving their disputes and reaching agreements on issues affecting the child is explicitly placed amongst the principal purposes of this procedure (art. 331).

The legislator also envisaged some specific rules to be applied in the decision making process about the contact between the child and the parent. Namely, art. 416 of the FA obliges the court to give the child an opportunity to express its views prior to making a decision on the matter of contact. Since the court decides on the issue of contact when there is no agreement between parents, the latter should be mindful of the fact the court will take into account their cooperativity with regards the proceedings of mandatory counselling and family mediation, and with regard to encouraging the contacts of the child with the other parent. The court is also under the obligation to warn the parents about the exercise of contact being especially important for the child's well-being and to encourage them to reach an

92 For spouses with children, parenting plan represents a condition for obtaining decision on non-contentious divorce. See arts. 52-55, art. 327 of the FA.

93 Mandatory counselling is a form of aid provided to family members for the purposes of reaching an agreement on family matters. See art. $321 / 1$ of the FA. 
agreement and to participate in family mediation. The explanation of the court's decision must include a warning about the possible sanctions for a parent who does not comply with the duty of enabling the child's contact with the other par$\mathrm{ent}^{94}$, which include fines, imprisonment, and the modification of decision on the child's place of residence (art. 417).

Croatian family law obviously asserts the view that joint parental responsibility is to the child's benefit, regardless of the parents' mutual relationship, hence it imposes upon them the duty to cooperate even when they do not live together or their relationship is conflictive. Of course, the latter situation can turn the joint parental responsibility into a burden, especially for the residing parent ${ }^{95}$, but also for the child who is caught in between parents. Besides that, the parents should have in mind that their child's right to participation implies that including the child should not only be a momentary act, but the starting point for an intense exchange between children and adults ${ }^{96}$, thus building a cooperative relationship between them.

In this context it is also worth mentioning that all the proceedings on the matters related to the child's personal rights are explicitly defined as urgent, with the courts being required to hold the first hearing within 15 days since the application was made. However, exceeding the time limits is allowed on account of important reasons (art. 347), which provided courts with the grounds to justify delays that were simply inevitable due to COVID-19 related measures.

When it comes to the child's procedural rights, the FA is in line with demands of both the European Convention on the Exercise of the Children's Rights and the Convention on Contact concerning Children and is providing those guarantees in all the proceedings affecting the child's rights. ${ }^{97}$ For instance, child is a party to all the judicial proceedings affecting its rights and interests (art. 358); in proceedings on matters affecting the child's personal rights and interests the court may allow the child who has reached the age of 14 to present the facts, submit evidence, lodge legal remedies and take other actions in those proceedings (art. 359/1); the court will give the child the opportunity to express its views, and it must also be satisfied that the child receives information about the proceedings (art. 360).

\footnotetext{
94 Arts. 418-419 FA also provide for a number of safeguards and guarantees which should contribute to carrying into effect of decisions on contact. Those measures fully correspond to the requirements of arts. 9 and 10 of the Convention on contact Concerning Children.

95 Korać Graovac, op. cit., note 85, p. 85.

96 UN Committee on the Rights of the Child, op. cit., note 19, pt. 13.

97 Lulić; Rešetar, op. cit., note 64, pp. 109-110.
} 
Notwithstanding the relevant legal framework which formally offers significant guarantees, children are faced with a number of barriers to the effective exercising of their procedural rights. ${ }^{98}$ This assertion is valid in the 'regular' circumstance which means that all the usual obstacles to that end were exacerbated when the quarantine was imposed to an extent that could almost be equalized to the annulment of those rights.

\section{MEASURES CONCERNING MAINTAINING CONTACT BETWEEN THE CHILD AND THE PARENTS DURING LOCK- DOWN}

Due to significantly increased risk of transmission of COVID-19, on 19 March 2020 the Civil Protection Headquarters of the Republic of Croatia (Headquarters) adopted the Decision on the temporary ban on crossing the state border at the border crossings of the Republic of Croatia ${ }^{99}$, which was followed by the Decision on prohibition on leaving the place of residence and permanent residence in the Republic of Croatia ${ }^{100}$, adopted on 23 March 2020. In an effort to reduce the possibility of further spread of the disease, these decisions imposed a complete lock-down and practically put the country in quarantine by placing severe restrictions of freedom of movement internationally and within the country.

The latter decision allowed for certain exceptions so the prohibition did not include leaving the place of residence due to vital family reasons such as the care of children (pt. II/e). Leaving the place of residence was possible only if a special permit for entry or exit was issued by the local civil protection headquarters. In any case, all the measures related to social distancing, not staying in public areas, and possession of a valid permit when entering or leaving the area of permanent residence had to be observed (pt. III). Therefore, children and parents residing in different states basically lost any possibility of having direct contact while the ban

98 Poretti, P., Pristup pravosudu za djecu, in: Župan, M. (ed.), Prekogranično kretanje djece u Europskoj uniji, Pravni fakultet Sveučilišta Josipa Jurja Strossmayera u Osijeku, Osijek, 2019, pp. 76-77. The author writes about the subjective barriers, explaining them as being conditioned by the characteristics of the child as a holder of rights, and the objective/systemic barriers, meaning the vicinity and accessibility of the court, adaptation of the court to the child as a party, legal assistance. Ibid., pp. 76-81

99 Odluka o privremenoj zabrani prelaska preko graničnih prijelaza Republike Hrvatske, Narodne novine, no. 32/20, 48/20, 56/2020. This Decision was amended many times since May 2020, almost on the monthly basis, by extending the period of application, softening the restrictions, introducing conditions relating to COVID-19 tests and etc. For more information, see e.g. [https://civilna-zastita. gov.hr/odluke-stozera-civilne-zastite-rh-za-sprecavanje-sirenja-zaraze-koronavirusom/2304], Accessed 1 April 2021.

100 Odluka o zabrani napuštanja mjesta prebivališta i stalnog boravka u Republici Hrvatskoj, Narodne novine, no. 35/20, 39/20, 44/20, 48/20, 56/20. 
was in force, while those children and parents residing in Croatia faced more or less obstacles in that regard, depending mostly on their individual circumstances and the interpretation the local headquarters decided to give to 'the vital family reasons' and 'care for children'.

Prohibition of cross-border travel was loosened by opening borders for Croatian citizens on 9 May 2020 under the strict condition of following the recommendations of the Croatian Institute of Public Health. Also, an exception to the prohibition was added so that persons travelling for urgent personal reasons were now included. ${ }^{101}$ After that the restrictions were gradually eased, as the situation allowed. Prohibition of leaving the place of residence was lifted completely on 11 May 2020. ${ }^{102}$

Prompted by frequent written submissions and phone calls from parents who are not living together and from the centres for social welfare because of the difficulties in exercising contacts between children and their non-resident parents, on 1 April 2020 the Ministry of Labour, Pension System, Family and Social Policy (the Ministry) published a Recommendation on maintaining contacts of children and parents and exercising parental responsibilities in the circumstances of pandemic ${ }^{103}$. The Ministry explicitly pointed out that it is primarily the duty and responsibility of parents to make effort in reaching the agreements and adapting their relations with their children in accordance with the measures imposed for the purposes of containing the spread of COVID-19, and to protect the health of the child.

If exercising direct contacts between the child and the non-resident parent would not be in accordance with all the measures prescribed by the Headquarters and/or keeping such contacts would increase the risk of infections, it was recommended that the contacts be exercised indirectly, via electronic and/or telecommunication means e.g. telephone, Skype, WhatsApp, Viber etc. While those conditions applied, the resident parent was to enable the child to make use of those means for the purposes of maintaining contact with the other parent to the maximum possible extent. In sum, direct contacts were not officially forbidden, however, generally imposed restrictions itself surely made them impossible for some children and

101 Odluka o izmjenama i dopuni Odluke o privremenoj zabrani prelaska preko graničnih prijelaza Republike Hrvatske, Narodne novine, no. 56/2020, pts. I and II.

102 Odluka o stavljanju izvan snage Odluke o zabrani napuštanja mjesta prebivališta i stalnog boravka u Republici Hrvatskoj, Narodne novine, no. 56/2020.

103 Ministarstvo za demografiju, obitelj, mlade i socijalnu politiku, Preporuka - Održavanje osobnih odnosa djece $s$ roditeljima i izvršavanje roditeljske skrbi u uvjetima pandemija, 1.4.2020., [https:// www.koronavirus.hr/najnovije/preporuka-odrzavanje-osobnih-odnosa-djece-s-roditeljima-i-izvrsavanje-roditeljske-skrbi-u-uvjetima-pandemija/366], Accessed 13 January 2021. 
parents. Also, they were, obviously, almost completely left to the will of parents and their capability for cooperation.

The Ministry reminded that the inability to recognize and prioritize the child's need for stability and health protection stands for violation of the child's rights which implies the possibility and/or the necessity of taking other actions in the area of family law or criminal law protection of the child. The Centres were recommended to pass this reminder on to parents.

Another thing that stands out is the fact the Ministry expressly stated that parental conflicts regarding maintaining personal contacts between children and parents are not considered as emergency situations. It would seem that this explicit remark may have implied that the parents must be aware of the impossibility of obtaining access to courts during the lock-down for the purposes of resolving their disputes regarding the issue of contact and are therefore forced to cooperate. This, we believe, is the area that offers significant space for improvement. The state should make more effort in educating parents not only of their legal responsibilities, rights and duties pertaining to parental responsibility, but also of all the consequences that could result from the inadequate performance of their role.

Centres for social welfare were instructed to take an individualized approach to every single situation and possibilities or limitations in maintaining contact, first of all taking into account the risks to the health of the child. ${ }^{104}$ For those parents who are not able to reach agreements themselves, the Ministry recommended ${ }^{105}$ using the counselling services and family mediation as very efficient methods of preventing the escalation of conflicts within family.

Inevitably, the operating of social services during the period of maximum restrictions was significantly reduced. The centres for social welfare were forced to close their doors and received clients only in urgent situations which could not be remedied any other way ${ }^{106}$ and it is doubtful whether the circumstances enabled responding even to all of the really urgent situations where the child's life, health, development and/or safety were endangered. Not unlike centres for social welfare, during the period of lock-down family centres also operated solely through the

104 Ministarstvo za demografiju, obitelj, mlade i socijalnu politiku, Održavanje osobnih odnosa djece s roditeljima i izvršavanje roditeljske skrbi u uvjetima pandemija, 31.3.2020., [http://czss-osijek.hr/ wp-content/uploads/2020/04/CZSS-SVI-odr\%C5\%BEavanje-osobnih-odnosa.pdf], Accessed 13 January 2021.

105 See: [https://mrosp.gov.hr/print.aspx?id=11816\&url=print], Accessed 18 January 2021.

106 See e.g. notifications of Centres for social welfare in Split - [https://czss-split.hr/index.php/novosti/193-obavijest-o-radu-centra], Osijek - [http://czss-osijek.hr/obavijest-gradanima/], Našice [http://www.czss-nasice.hr/obavijest-gradanima/], Accessed 19 January 2021. 
electronic means of communication ${ }^{107}$ which represented another significant obstacle $^{108}$ in the process of providing counselling as well as participating in that process.

The Ministry monitored the course of events and on 11 May 2020 issued a fresh Recommendation on maintaining contacts between the child and the non-resident parent ${ }^{109}$, stating that contacts are to be exercised according to the courts' decisions in force. However, the restrictions will apply in case one of the parents or another member of their family end up in self-isolation or infected with COVID-19. In all other circumstances, it is again the parents responsibility to assess the interest of their child depending on its state of health as well as the health of each parent's household members.

The Ministry reminded the interested parties about the possibility of reaching out to social welfare centres for professional assistance. The possibility of family and household members coming under the obligation of isolation or self-isolation probably resulted in many different variations of restrictions which would apply to contacts of the child and the parent, so even after the lock-down ended the circumstances were still a fertile ground for conflicts regarding maintaining direct contact.

At this point we do not have relevant specific data to conduct comprehensive analysis of the actual effects of COVID-19 lock-down on the right of the child in Croatia to maintain contact with the non-resident parent. Presumably, exercising the right to contact was considered as "vital family reason of caring for the child", however we do not know how many permits were issued on the grounds of that exception to the prohibition on leaving the place of permanent residence ${ }^{110}$, or

107 See: [https://mrosp.gov.hr/print.aspx?id=11816\&url=print], Accessed 18 January 2021, op. cit., note 88.

108 For instance, Croatian government set up funding schemes to provide laptops or other technological devices for children who were otherwise unable to access online learning. See: Council of Europe, op. cit., note $1, \mathrm{p} .16$. This is certainly a commendable measure and one that should be considered in the future in a wider context of providing assistance to the families in need.

109 Ministarstvo za demografiju, obitelj, mlade i socijalnu politiku, Preporuka - Održavanje osobnih odnosa djeteta s roditeljem s kojim ne stanuje, 11.5.2020., [https://mrosp.gov.hr/UserDocsImages/dokumenti/COVID-19/3_Preporuka\%20roditeljima\%2011.5..pdf], Accessed 19 January 2021.

110 By 18 May 2020, when the obligation of obtaining them way cancelled, there were 2,202,518 permits issued, [https://www.dw.com/hr/hrvatska-bez-e-propusnica-jednog-od-najefikasnijih-oru\%C4\%91a-u-sprje\%C4\%8Davanju-\%C5\%A1irenja-zaraze/a-53474226], Accessed 13 January 2021. However, we do not know how many of them were issued for the purposes of caring for the child and whether exercising the right to contact was actually treated as a vital family reason. Generally, circumstances regarding issuing permits were rather vague, lacking transparency and predictability. 
how many contacts were missed due to condition of obtaining the permit itself. We still do not know how many court proceedings were halted or delayed, or how many proceedings were initiated during the period of severe restrictions of freedom of movement as a result of parents' disagreements about the way of exercising the right to contact; also, we do not know how many disputes concerning contact were successfully resolved during that period, using the means available.

Publicly available case-law of the Croatian courts so far does not suggest a large number of such proceedings. ${ }^{111}$ Available decisions which are both related to the right of contact and mention COVID-19 restrictive measures from the period after the lock-down ended suggest that, in principle, those restrictions were not seen as obstacles for maintaining contact between the child and the parent. However, two cases suggest that the lock-down was (ab)used by one of the parents to the detriment of the child's contact with the other parent. One case concerns the mother moving to another city claiming that it was safer there due to a better epidemiological situation and that the children were not safe when staying with their father ${ }^{112}$. Circumstances of another case suggest that the father used the period of lock-down, which the child spent with him on the basis of the parents' agreement, to manipulate the child against its mother. ${ }^{113}$

What we find encouraging and where we see an opportunity for learning from this experience and for further improvement, is the fact that some of the court's decisions mentioned above contain specific references to the relevant provisions of the international instruments protecting the child's right to contact with its parents,

111 See: Županijski sud u Puli-Pola, Gž Ob-277/2020-2, 14.9.2020., where the decision includes an instruction to the parents about their obligation to respect all the decisions and the recommendations of the Croatian Institute for Public Health and the Headquarters while the pandemic is ongoing; Županijski sud u Puli-Pola, Gž Ob-367/2020-2, 1.12.2020., where the father claimed COVID-19 restrictions prevented him from visiting his children placed in SOS Children's Village L., however the court rejected that argument because there was no evidence that the father ever requested the permit for leaving his place of residence; Županijski sud u Splitu, Gž Ob-819/2020-2, 3.12.2020., where the court rejected mother's argument against determining the location for contacts at the local shopping centre since such places have not been identified as the sources of jeopardy for public health in the context of COVID-19 pandemic, provided that protective measures are applied.

112 Županijski sud u Puli-Pola, Gž Ob-357/2020-2, 16.11.2020. Mother appealed against the decision determining the place of residence of her children at the address of their father in Zagreb and the contact arrangements. She moved with two daughters from Zagreb to Umag, claiming it was safer there due to minimal risk of earthquakes in Istra and due to a better epidemiological situation. In her appeal she claimed children were in danger when staying with their father in Zagreb.

113 Županijski sud u Puli-Pola, Gž Ob-257/2020-2, 1.9.2020. The father is retired and the mother is working so they agreed upon child staying with the father during COVID-19 pandemic and while the online classes were on. However, the child gradually started resisting visiting its mother. The court found that that the child's behaviour was the result of the father's manipulation as the child had previously lived with its mother since the day of birth till the pandemic broke out. 
with which the courts tried to made parents more aware of their duties regarding enabling the child in exercising that right. As mentioned earlier, art. 417 of the FA obliges the courts to inform the parents about the significance of maintaining contact with both of them and to warn them of the possible sanctions for violating their duties thereof. We believe that there is a space for further improvement in this area also.

\section{CONCLUSION}

The international community expressed its view regarding the rights of the child who is not able to live with both parents through, inter alia, recognizing the child's right to contact with the parent from whom it is separated in order to preserve their relationship ${ }^{114}$, and the Croatian legal framework is definitely abiding to that consensus. It recognises that the right to contacts is equally important for the child and the parents and it recognizes the child's procedural rights. It also accentuates the cooperation between parents and between parents and children as a crucial element in building positive relationship between the child and both parents.

In general, the state has the role of the protector of the family and the child, however it is often the case that the state does not rise up to the challenge of its duties or the state is the one violating the rights of parents and children ${ }^{115}$. That being said in the context of the still ongoing pandemic, it is obvious that fulfilling the protective role of the state with regard to exercising the right to contact between children and parents was significantly compromised for objective reasons. For instance, social services in Croatia were already over-stretched and in need of reform and the pandemic only further amplified these deficiencies. ${ }^{116}$

It was not necessary to describe in detail in this article the extent to which children's everyday lives were disturbed by the global lock-down, with closing down everything and confining everyone to their homes. Today, we are all still sharing the experience of this global crisis. Moreover, it is safe to say at this point that we do not know when the pandemic will be over. Even though the lock-down is no longer in force, a lot of other restrictions are. Nobody expected this state of emergency to last this long, so there is no point to just keep waiting 'for all of this to be over' and the competent authorities should take this opportunity to learn from the experiences that the crisis brought.

\footnotetext{
114 Jakovac-Lozić, op. cit., note 4, p. 870.

115 Vučković Šahović; Petrušić, op. cit., note 9, p. 140.

116 Mutatis mutandis: Council of Europe, op. cit., note 1, p. 3.
} 
Examination of the relevant legal framework for the child's right to maintain regular contact with both parents revealed not only what rights children and parents have in that regard and what the role of the state and the competent authorities entails, but it revealed also the extent to which those rights and duties were objectively and effectively disabled. There are so many legal tools aimed at protecting and promoting the child's rights, but they were simply unfeasible. Contact issues were left to parents to agree upon, but many parents are not capable of resolving such issues in the spirit of cooperation, putting their child's interest in front of their own.

Precisely in this regard the pandemic revealed a need to further develop counselling services. Also, the competent authorities shoud initiate educative activities aimed primarily at parents, with a view of educating and counselling them about the contents and significance of their parental role, and the crucial influence of cooperation on their family relations. Parents should be made aware that the child's rights are not just a few words on a paper archived somewhere far away in the United Nations or the Council of Europe; they must be fully aware that those words are written in the national legislation and that not acting in accordance with their parental responsibilities may result in certain sanctions.

It is our belief that even if COVID-19 was to disappear tomorrow, this would still be a good investment, so to say, for the future. The skills acquired through participation in such educational and counselling activities would stay with that family even after the pandemic is over, and would generally contribute to reducing the level of conflict and raising the level of cooperation in resolving family matters, thus reducing the need for engaging the judicial or social welfare system. For those who need a stronger incentive, more efforts should be put within the judicial system, respectively through empowering judges who decide on family matters. Their duties in that regard also include making parents aware of the importance of the child's right to maintain meaningful contact with both of them, warning them about the legal consequences they may face in case they do not comply with their responsibilities, but they also include deciding on such consequences.

\section{REFERENCES}

\section{BOOKS AND ARTICLES}

1. Alinčić, M.; Hrabar, D.; Jakovac-Lozić, D.; Korać Graovac, A., Obiteljsko pravo, Narodne novine, Zagreb, 2007

2. Bubić, S., Standard najbolji interes djeteta i njegova primjena u kontekstu ostvarivanja roditeljskog staranja, Zbornik radova Dani porodičnog prava 'Najbolji interes djeteta u zakonodavstvu i praksi”, Pravni fakultet Univerziteta 'Džemal Bijedić", Mostar, 2014, pp. 11-31 
3. Faye Jacobsen, A., Children's Rights in the European Court of Human Rights - An Emerging Power Structure, The International Journal of Children's Rights, 24:3, pp. 548-574

4. Freeman, M., A Commentary on the United Nations Convention on the Rights of the Child, Article 3: The Best Interests of the Child, Martinus Nijhoff Publishers, Leiden-Boston, 2007

5. Harris, D.J.; O’Boyle, M.; Bates, E.P.; Buckley, M., Harris, O’Boyle \& Warbrick: Law of the European Convention on Human Rights, Oxford University Press, 2014

6. Hodgkin, R.; Newell, P., Implementation Handbook for the Convention on the Rights of the Child, United Nations Children's Fund, Geneva, New York, 2007

7. Hrabar, D., Dijete-pravni subjekt u obitelji, Zagreb, 1994

8. Jakovac-Lozić, D., Medunarodne otmice djece od strane roditelja, Zbornik radova Pravnog fakulteta u Splitu, Vol. 34, No. 45-46, 1997, pp. 73-96

9. Jakovac-Lozić, D., Europska konvencija o kontaktima u vezi s djecom (2003.) i prilagodba obiteljskog zakonodavstva Federacije Bosne i Hercegovine zahtjevima Konvencije de lege ferenda, Zbornik radova Aktualnosti građanskog i trgovačkog zakonodavstva i pravne prakse, no. 2, Mostar, 2004, pp. 147-184

10. Jakovac-Lozić, D., Susreti i druženja djeteta s odvojenim roditeljem u presudama Europskog suda za ljudska prava, Zbornik Pravnog fakulteta u Zagrebu, vol. 55, no. 3-4, 2005, pp. 869-925

11. Khazova, O.A.; Mezmur, B.D., Continued Reflections on Family Law Issues in the Jurisprudence of the CRC Committee: The Convention on the Rights of the Child @ 30, in: Brinig, M. (ed.), International Survey of Family Law, Intersentia, Cambridge-Antwerp-Chicago, 2020, pp. 337-363

12. Kilkelly, U., Children's Rights - A European Perspective, Judicial Studies Institute Journal, 2004, 4:2, pp. 68-95

13. Korać Graovac, A., Zajednička roditeljska skrb u praksi Europskog suda za ljudska prava - slučaj Zaunegger v. Germany, in: Rešetar, B. (ed.), Pravna zaštita prava na (zajedničku) roditeljsku skrb, Pravni fakultet u Osijeku, Osijek, 2012, pp. 72-88

14. Korać Graovac, A. Povelja o temeljnim pravima Europske unije i obiteljsko pravo, in: Bodiroga-Vukobrat, N. et al. (eds.), Europsko obiteljsko pravo, Narodne novine, Zagreb, 2013, pp. $25-51$

15. Lopatka, A., An Introduction to the United Nations Convention on the Rights of the Child, Transnational Law and Contemporary Problems, Vol. 6, 1996, pp. 251-262

16. Lulić, M.; Rešetar, B., Međunarodne obveze Republike Hrvatske vezane uz provedbu Konvencije o kontaktima s djecom (2003), in: Rešetar, B. (ed.), Pravna zaštita prava na (zajedničku) roditeljsku skrb, Pravni fakultet u Osijeku, Osijek, 2012, pp. 89-119

17. McEleavy, P., Brussels II bis: Matrimonial Matters, Parental Responsibility, Child Abduction and Mutual Recognition, The International and Comparative Law Quarterly, Vol. 53, No. 2, 2004, pp. 503-512

18. Nikolina, N., Divided Parents, Shared Children: Legal Aspects of (Residential) Co-Parenting in England, the Netherlands and Belgium, Intersentia, Cambridge-Antwerp-Portland, 2015

19. Parkes, A., Children and International Human Rights Law: The Right of the Child to be Heard, Routledge, London, 2013 
20. Poretti, P., Pristup pravosudu za djecu, in: Župan, M. (ed.), Prekogranično kretanje djece u Europskoj uniji, Pravni fakultet Sveučilišta Josipa Jurja Strossmayera u Osijeku, Osijek, 2019

21. Rešetar, B., Pravna zaštita prava na susrete i druženje, Pravni fakultet u Osijeku, Osijek, 2011

22. Roagna, I., Protecting the right to respect for private and family life under the European Convention on Human Rights, Council of Europe, Strasbourg, 2012

23. Vertommen, E., Balancing the Rights of Parent and Child in Case on Non-Compliance with Contact Arrangements: A Case Law Analysis, in: Boele-Woelki, K.; Martiny, D. (eds.), Plurality and Diversity of Family Relations in Europe, Intersentia, Cambridge, 2019, pp. 175-201

24. Vučković Šahović, N.; Petrušić, N., Prava deteta, Pravni fakultet Univerziteta u Nišu, Niš, 2016

\section{INTERNATIONAL LAW}

1. Europska konvencija o ostvarivanju dječjih prava (European Convention on the Exercise of Children's Rights), Narodne novine - Međunarodni ugovori, no. 1/10, 3/10

2. Konvencija o kontaktima s djecom (Convention on Contact concerning Children), Narodne novine - Međunarodni ugovori, no. 7/08, 1/09

3. Konvencija o pravima djeteta (Convention on the Rights of the Child), Službeni list SFRJ - Međunarodni ugovori, no. 15/90, Narodne novine - Međunarodni ugovori, no. 12/93, 20/97, 4/98, 13/98

4. Konvencija za zaštitu ljudskih prava i temeljnih sloboda te Protokoli br. 1, 4, 6, 7, 11, 12, 13, 14, 15 (Convention for the Protection of Human Rights and Fundamental Freedoms and its Protocols Nos. 1, 4, 6, 7, 11, 12, 13, 14, 15), Narodne novine - Međunarodni ugovori, no. $18 / 97,6 / 99,14 / 02,13 / 03,9 / 05,1 / 06,2 / 10,13 / 17$

\section{EU LAW}

1. Charter of Fundamental Rights of the European Union, OJ C 326, 26.10.2012

2. Consolidated version of the Treaty on European Union, OJ C 326, 26.10.2012

3. Consolidated version of the Treaty on the Functioning of the European Union, OJ C 326, 26.10.2012

4. Council Regulation (EC) No 2201/2003 of 27 November 2003 concerning jurisdiction and the recognition and enforcement of judgments in matrimonial matters and the matters of parental responsibility, repealing Regulation (EC) No 1347/2000, OJ L 338, 23.12.2003

5. Treaty of Lisbon amending the Treaty on European Union and the Treaty establishing the European Community, OJ C 306, 17.12.2007

\section{ECHR}

1. A.K. and L. v. Croatia, no. 37956/11, 8 January 2013

2. A.V. v. Slovenia, no. 878/13, 9 April 2019

3. C. v. Finland, no. 18249/02, 9 May 2006, 
4. Ignaccolo-Zenide v. Romania, no. 31679/96, 25 January 2000

5. Jeunesse v. the Netherlands [GC], no. 12738/10, 3 October 2014

6. Johansen v. Norway, no. 17383/90, 7 August 1990

7. Kacper Nowakowski v. Poland, no. 32407/13, 10 January 2017

8. Kocherov and Sergeyeva v. Russia, no. 16899/13

9. N.Ts. v. Georgia, no. 71776/12, 2 February 2016

10. Pavel Shishkov, no. 78754/13, 2 March 2021

11. Petrov and X v. Russia, no. 23608/16, 23 October 2018

12. Ribić v. Croatia, no. 27148/12, 2 April 2015

13. Sommerfeld v. Germany [GC], no. 31871/96, 8 July 2003

14. Strand Lobben and Others v. Norway, no. 37283/13, 10 September 2019

15. Suur v. Estonia, no. 41736/18, 20 October 2020

16. V. v. Slovenia, no. 26972/07, 1 December 2011

17. V.D. and Others v. Russia, no. 72931/10, 9 April 2019

18. Z. v. Poland, no. 34694/06, 20 April 2010

\section{COURT OF JUSTICE OF THE EUROPEAN UNION}

1. C540/03, 27 June 2006

2. C400/10 PPU, 5 October 2010

3. C-498/14 PPU, 9 January 2015

4. C499/15, 15 February 2017

5. C-335/17, 31 May 2018

6. C512/17, 28 June 2018

7. C393/18 PPU, 17 October 2018

8. C-454/19, 19 November 2020

9. C-603/20 PPU, 24 March 2021

\section{LIST OF NATIONAL REGULATIONS, ACTS AND COURT DECISIONS}

1. Obiteljski zakon, Narodne novine, no. 103/15, 98/19, 47/20

2. Odluka o privremenoj zabrani prelaska preko graničnih prijelaza Republike Hrvatske, Narodne novine, br. 32/20, 48/20, 56/2020

3. Odluka o izmjenama i dopuni Odluke o privremenoj zabrani prelaska preko graničnih prijelaza Republike Hrvatske, Narodne novine, no. 56/2020

4. Odluka o zabrani napuštanja mjesta prebivališta i stalnog boravka u Republici Hrvatskoj, Narodne novine, br. 35/20, 39/20, 44/20, 48/20, 56/20

5. Odluka o stavljanju izvan snage Odluke o zabrani napuštanja mjesta prebivališta i stalnog boravka u Republici Hrvatskoj, Narodne novine, no. 56/2020

6. Županijski sud u Puli-Pola, Gž Ob-257/2020-2, 1.9.2020. 
7. Županijski sud u Puli-Pola, Gž Ob-277/2020-2, 14.9.2020.

8. Županijski sud u Puli-Pola, Gž Ob-357/2020-2, 16.11.2020.

9. Županijski sud u Puli-Pola, Gž Ob-367/2020-2, 1.12.2020.

10. Županijski sud u Splitu, Gž Ob-819/2020-2, 3.12.2020.

\section{WEBSITE REFERENCES}

1. Council of Europe, Explanatory Report to the Convention on Contact concerning Children, Strasbourg, 2003, [https://rm.coe.int/CoERMPublicCommonSearchServices/Displa yDCTMContent?documentId=09000016800d380d], Accessed 25 January 2021

2. Council of Europe, Explanatory Report to the European Convention on the Exercise of Children's Rights, 1996, [https://rm.coe.int/CoERMPublicCommonSearchServices/Displa yDCTMContent?documentId=09000016800cb5ee], Accessed 11April 2021

3. Council of Europe, The COVID-19 pandemic and children: Challenges, responses and policy implications, 2021, [https://rm.coe.int/covid-19-factsheet-revised-eng/1680a188f2], Accessed 9 June 2021

4. Ministarstvo za demografiju, obitelj, mlade i socijalnu politiku, Preporuka - Održavanje osobnih odnosa djece s roditeljima i izvršavanje roditeljske skrbi u uvjetima pandemija, [https://www.koronavirus.hr/najnovije/preporuka-odrzavanje-osobnih-odnosa-djece-sroditeljima-i-izvrsavanje-roditeljske-skrbi-u-uvjetima-pandemija/366], Accessed 13 January 2021

5. Ministarstvo za demografiju, obitelj, mlade i socijalnu politiku, Održavanje osobnih odnosa djece s roditeljima i izvršavanje roditeljske skrbi u uvjetima pandemija, [http://czss-osijek. hr/wp-content/uploads/2020/04/CZSS-SVI-odr\%C5\%BEavanje-osobnih-odnosa.pdf], Accessed 13 January 2021

6. Ministarstvo za demografiju, obitelj, mlade i socijalnu politiku, Preporuka - Održavanje osobnih odnosa djeteta s roditeljem s kojim ne stanuje, [https://mrosp.gov.hr/UserDocsImages/dokumenti/COVID-19/3_Preporuka\%20roditeljima\%2011.5..pdf], Accessed 19 January 2021

7. UN Committee on the Rights of the Child, General Comment No 12 (2009): The right of the child to be heard, CRC/C/GC/12, 20 July 2009, [https://www2.ohchr.org/english/bodies/crc/docs/AdvanceVersions/CRC-C-GC-12.pdf], Accessed 28 January 2021

8. UN Committee on the Rights of the Child, General comment No. 14 (2013) on the right of the child to have his or her best interests taken as a primary consideration (art. 3, para. 1), CRC/C/GC/14, 29 May 2013, [https://www2.ohchr.org/English/bodies/crc/docs/GC/ CRC_C_GC_14_ENG.pdf], Accessed 28 January 2021 